\title{
How do you know I was about to say "book”? Anticipation processes affect speech processing and lexical recognition.
}

\author{
Alice Foucart ${ }^{1}$, Elisa Ruiz-Tada ${ }^{1}$ \& Albert Costa ${ }^{1,2}$
}

1- $\quad$ Center for Brain and Cognition, University Pompeu Fabra, carrer Roc Boronat, 138, 08018 Barcelona, Spain

2- $\quad$ ICREA, Institució Catalana de Recerca i Estudis Avançats, Barcelona, Spain

Corresponding author:

Dr. Alice Foucart

Universitat Pompeu Fabra

Department of Technology (room 55116)

Roc Boronat, 138, 08018

Barcelona

Spain

Phone: +34 935422362

Email: alfoucart@gmail.com

Word count: 6967 words (including references)

\section{Acknowledgements}

This work was supported by grants from the Spanish Government (PSI2011-23033, CONSOLIDER-INGENIO2010 CSD2007-00048, ECO2011-25295, and ECO201009555-E), from the Catalan Government (SGR 2009-1521) and from the 7th Framework Programme (AThEME 613465). We would like to thank Ziggy Campbell for his technical advice on the preparation of the audio stimuli and Dr Clara Martin for her useful comments. 


\section{Abstract}

Most ERP studies that showed the role of anticipation processes during sentence processing focused on sentence reading. However, in everyday conversation speech unfolds at higher speed; the present study examines whether comprehenders also anticipate upcoming words when processing auditory sentences. In auditory highconstrained Spanish sentences, we time-locked ERPs on the article preceding the critical noun. Importantly, to avoid overlapping effects, the critical noun was muted. Articles that mis-matched the gender of the expected nouns triggered an early (200-280 ms) and a late negativity (450-900ms), suggesting that anticipation processes are at play also during speech processing. A subsequent lexical recognition task revealed that, although both “expected" and "unexpected" words were muted during the listening phase, “expected” words were (falsely) recognized significantly more often than "unexpected” words, and as often as "old" words that were actually presented. These results suggest that anticipation processes allow creating a memory trace of a word prior to presentation. The findings support a top-down view of spoken sentence comprehension.

Keywords: Anticipation processes; speech processing; spoken word recognition, ERPs, top-down information. 
A substantial body of research has shown that language comprehension involves anticipatory processes (DeLong, Urbach, \& Kutas, 2005; Foucart, Martin, Moreno, \& Costa, 2014; Martin et al., 2013; Otten, Nieuwland, \& Van Berkum, 2007; Van Berkum, Brown, Zwitserlood, Kooijman, \& Hagoort, 2005; Wicha, Bates, Moreno, \& Kutas, 2003; Wicha, Moreno, \& Kutas, 2004). That is, comprehenders take an active role when processing a sentence by predicting upcoming words as the sentence unfolds. These anticipatory processes have been argued to ease communicative interactions (Pickering \& Garrod, 2007). However, these studies suffer from an important limitation when used to inform speech comprehension processes. Namely, most studies have made use of sentences presented visually, at a relatively slow pace (but see, Otten et al., 2007; Van Berkum et al., 2005; Wicha, et al., 2003). This slow pace is certainly a feature that departs very much from regular communicative interactions in which the flow of speech is fast. For instance, the average speaker produces between 150 and 190 words per minute in English (Marslen-Wilson, 1973; Riding \& Vincent, 1980) and up to 205 in Spanish (Navarro, 1950). The question arises of whether comprehenders can also take an active role anticipating upcoming words when faced with speech that runs at such high speed. This is precisely the question addressed in the current article.

We assess the issue of the comprehender's active role by exploring the event-related brain potentials (ERPs) elicited during speech language comprehension. Many ERP studies have demonstrated the influence of sentence context on semantic processing. The common finding is a reduction of the N400 component (usually associated to semantic processing) for nouns that are highly expected from the context compared to nouns that are less expected but still fit semantically (Federmeier \& Kutas, 1999; Federmeier, Wlotko, De Ochoa-Dewald, \& Kutas, 2007). For example, in the sentence "I'm on my way to the library to return a...", the word "book" would elicit a reduced 
N400 component compared to the word "film" that perfectly fits within the context but is less expected. These studies, however, do not allow dissociating whether this reduction reflects integration processes, anticipation processes, or both. Indeed, as proposed by the "passive resonance" hypothesis, the integration of the word "book" is facilitated upon its presentation because it matches the semantic network activated by the sentence context (Kuperberg, Paczynski, \& Ditman, 2011; Myers \& O’Brien, 1998; Paczynski \& Kuperberg, 2012). Alternatively, the “active lexical prediction” proposal assumes that such a reduction in the N400 component stems from the ability to anticipate words as the sentence unfolds and hence before they are presented (DeLong, Urbach, \& Kutas, 2005; Neely, 1977, see Lau, Holcomb, \& Kuperberg, 2013, for an extensive discussion on the debate). It is important to note that these two proposals are not mutually exclusive and that anticipation and integration processes might be at play during sentence processing. Indeed, it is likely that, depending on the comprehension conditions (e.g., if the sentence context is distorted by noise), comprehenders may rely more on one or the other.

To dissociate whether the reduction of the N400 amplitude observed on the expected noun reflects passive integration only or active prediction recent studies have looked at the word directly preceding the noun. Using the phonological (DeLong et al., 2005; Martin et al., 2013) or syntactic features (Foucart et al., 2014; Otten et al., 2007; Van Berkum et al., 2005; Wicha et al., 2004; Wicha, Moreno, \& Kutas, 2003) of the preceding determiner or adjective, it has been observed that a noun is anticipated before it is actually presented. For example, Wicha et al. (2004) used high constrained sentences in which the gender of the expected and unexpected nouns differed, like in “Caperucita Roja llevaba la comida para su abuela en una[fem]canasta [fem] / un[masc] cesto[masc]" (Little Red Riding Hood carried the food for her grand-mother 
in a basket/hamper). They found that context effects were already present on the article preceding the noun, with reduced amplitude for the article that matched the gender of the expected noun compared to the article that matched that of the unexpected noun. The main conclusion of these studies is that both the noun and its features are actively anticipated, and that the features are used in real time to compute agreement and build up sentence meaning.

As mentioned earlier, these studies were conducted mainly in sentence reading with a word by word presentation of a minimum of $500 \mathrm{~ms}$ (300 ms word duration and $200 \mathrm{~ms}$ inter-stimulus interval), which is slower than the normal reading rate. Moreover, in ERP visual experiments words are read in their entirety, which contrasts with listening which involves words being processed from their onset onwards (see Rayner \& Clifton, 2009). Thus, it is possible that in high-speed conditions as in fluent speech, the role of anticipatory processes may be limited. This would concord with models of word recognition that reject the idea of prediction and support a bottom-up view (MarslenWilson, 1987, 1989; Norris, 1994).

There are, however, a few ERP studies that have shown some indication that anticipation processes take place also during speech processing. A technical problem when trying to investigate this question using ERP is discriminating between the ERP components elicited by the word preceding the noun and those generated by the noun itself as they may overlap. Recall that ideally one would like to explore anticipation effects without any contribution of the noun itself, since otherwise the effects could reflect integration processes. Wicha and colleagues intended to overcome this problem by replacing the (un-)expected noun by a picture (Wicha, Bates, et al., 2003). Indeed these authors reported an N400 for the unexpected article as compared to the expected one. However, this effect might have been altered by that triggered by the picture, since 
it was presented immediately after article offset. Van Berkum and colleagues also examined anticipation processes in auditory modality by looking at the effect triggered by the inflection of the adjective preceding the noun (e.g., een groot schilderij/een groote boekenkast, a big painting/a big bookcase) (Otten et al., 2007; Van Berkum et al., 2005). Adjectives that did not match with the expected noun elicited an early differential ERP effect but again, this effect might have also been affected by the effect elicited by the noun or by coarticulatory changes in the stem of the adjective due to the presence or absence of the suffix (see Van Berkum et al., 2005 for a discussion). Hence, although these two studies suggest the presence of anticipatory processes in speech comprehension they also have some limitations since the observed effects may also reflect the integration of the target noun.

In the present experiment we aim at overcoming this limitation by removing the target noun from the speech string. Specifically, we recorded participants' brain activity as they were listening to high-constraint sentences in Spanish. We used the same sentences as in Foucart et al. (Foucart et al., 2014), in which anticipation effects were observed on the article in visual modality. To avoid overlapping effects between the article and the noun we "muted" the noun (see Methods for more details); this manipulation affected both conditions (i.e., expected and unexpected) similarly. To make it sound more natural, we pretended the sentences were extracted from mobile phone conversations, as nowadays people are used to talking over devices and to interferences distorting speech fluency. Note that these "unnatural disfluences” contrast with disfluencies produced by the speaker such as hesitations (e.g., “er...”) or silences, which have been shown to decrease anticipation of the expected noun when occurring in the sentence context because they imply uncertainty from the speaker (Corley, MacGregor, \& Donaldson, 2007; MacGregor, Corley, \& Donaldson, 2010). Removing 
the (un-)expected noun from the sentence allows observing the effect elicited by the article; if anticipation processes take place during speech processing, we should observe different ERP amplitudes for the article matching the (muted) expected noun than for that matching the (muted) unexpected noun.

In addition, in the second part of the experiment, we asked participants to complete a lexical recognition task in which they had to indicate whether they had heard the word during the listening phase. They were presented with "new" words, "old” words (from filler sentences) and the “expected/unexpected” words (muted in the listening phase). This recognition task was designed to examine whether anticipation processes allow for a memory trace of a word that is not presented to be created. It tests Van Berkum's proposal that the word recognition system may benefit from word pre-activation (Van Berkum et al., 2005). In other words, if comprehenders rely more on integration processes during speech comprehension because the sentence context unfolds too fast, a word should be encoded only if presented; conversely, if comprehenders use linguistic cues incrementally to predict upcoming words as the sentence is spoken out, a word may be encoded even if it is not presented. If the latter case is correct, no difference should be observed between "expected" nouns that were muted during the listening phase and "old" nouns that were heard; on the other hand, a difference should be observed between “old” nouns and "unexpected” nouns since the latter are not expected from the sentence context.

\section{METHOD}

Participants:

Twenty-two (nine female) native Spanish speakers (mean age $=24.3$ years, range $=19$ 32 years) took part in the experiment. Participants were recruited from the university participant pool. They were right handed, had normal or corrected-to-normal vision, and 
reported no neural or auditory disorders. Before the experiment, all participants signed a consent form after receiving oral and written information of the procedure and experiment. The data of two participants were taken out due to equipment malfunction. Materials:

We used the same 52 highly constrained sentences used in Foucart et al. (2014). Sentences were in Spanish and had two possible noun outcomes: an expected noun and an unexpected noun (a total of 104 experimental sentences). These sentences were designed so that the expected and unexpected nouns differed in gender (e.g.: el tesoro [masculine] vs. la gruta [feminine]; see Table 1 for examples of sentences and Appendix 1 for a complete list of the materials). Expected and unexpected nouns were matched in frequency (expected: 50.9 per million, SD: 58.25; unexpected: 43.18 SD: $55.43 \mathrm{p}=0.36$ ) and length (mean 6 letters for both expected and unexpected, range of 4 to 9 letters for expected, 3 to 11 for unexpected), using the program Buscar Palabras (Davis \& Perea, 2005). Out of the 52 expected nouns, 28 were feminine nouns and 24 were masculine nouns (and vice-versa for the unexpected nouns).

The mean cloze probability of the expected nouns were previously assessed by native $(\mathrm{N}=12)$ Spanish speakers. They were asked to complete highly constrained sentences with the first word that came to their mind. The sentence was provided up to the word before the article, and therefore, participants could choose to complete the sentence with either gender (masculine or feminine). Mean cloze probability was 0.81 (SD: 0.19) and 0.04 (SD: 0.09) for expected and unexpected nouns, respectively. Another 52 sentences were created as filler sentences. These sentences contained nouns that were matched in frequency and length to the experimental nouns and that were presented as "old” words in the recognition task. The total 104 sentences were divided into two lists containing an equal number of expected and unexpected trials. Lists were balanced for noun gender, 
word frequency and length. Each sentence was heard only once in each list either in the expected or unexpected condition.

Table 1. Example of sentences

\section{Conditions}

\section{Examples}

Expected El pirata tenía el mapa secreto, pero nunca encontró el tesoro [masc] que buscaba.

Unexpected El pirata tenía el mapa secreto, pero nunca encontró la gruta [fem] que buscaba.

The pirate had the secret map, but he never found the treasure/the cave he was looking for.

Audio recording

Each sentence was recorded in its expected and unexpected version by a female native speaker of Spanish (resulting in 104 sentences, 52 in each condition). Recordings were then edited using the audio editing program Audacity (Version 2.0.2 http://audacity.sourceforge.net). We ensured sentences had an identical sentence context in both conditions by keeping one version of the recording (either expected or unexpected) up to the word preceding the article and then we spliced the rest of the sentence from the other condition. To reduce any bias due to cues (e.g., prosody, coarticulation) that may potentially convey information regarding the upcoming word, sentence contexts from the expected and unexpected conditions were selected equally (i.e., 52 from each condition). In each experimental sentence, the noun was completely muted for $500 \mathrm{~ms}$ after article offset and then the sentence resumed normally until the end (the 500 ms silence window covered the totality of the word with the exception of 
two words in each condition for which the silence was extended up to $550 \mathrm{~ms}$ ). The mean duration of the (muted) nouns was similar in the expected (345 ms, SD: $85 \mathrm{~ms}$ ) and unexpected conditions (350 ms, SD: $96 \mathrm{~ms}$ ). The average duration of the sentence context before article onset was 2835 ms (SD: $707 \mathrm{~ms}$ ) and that of the article was 124 ms (SD: $38 \mathrm{~ms}$ ). The article onset was found by audio and visual inspection of the spectrogram. The total duration of a sentence was $3802 \mathrm{~ms}$ (SD: $770 \mathrm{~ms}$ ). To avoid participants to guess the manipulation, we included silences (200 and $300 \mathrm{~ms}$ long) in the filler sentences at different positions in the sentence but never on the nouns that would then be presented as "old" words in the recognition task. Finally, to account for the interferences created by the silences, participants were told the sentences had been extracted from a phone call; hence, all sentences were equalized to reproduce a phonelike sound quality.

\section{Listening phase.}

Procedure:

Participants were sitting comfortably in front of a computer screen in a softly lit sound proof room. Instructions were given visually as well as verbally. Participants’ EEG data was recorded as they were listening to the sentences silently. The sentences were presented through two loudspeakers placed on either side of the screen using the software E-prime 2.0 (Schneider, Eschman, \& Zuccolotto, 2002a, 2002b). Participants were instructed to minimize blinking, eye movements and to stay still during the experiment. They were told they would be asked questions about the sentences after the listening phase (it was not specified that it was a lexical recognition task). One third of the sentences was followed by a yes-no question displayed on the screen to ensure participants were paying attention (97\% of correct answers; the answers were not 
further analysed). After a two sentence practice, participants were presented with one of the two lists, randomised for each participant. Each list contained 26 sentences in the "Expected" condition, 26 in the "Unexpected" condition, and 52 filler sentences. Each sentence was preceded by a white fixation cross displayed on the screen for $500 \mathrm{~ms}$; the cross turned red during sentence presentation. The listening phase lasted for about 15-20 min with a break half-way through the session.

EEG recording and data analysis

Electrophysiological data was recorded from 31 tin electrodes attached to an elastic cap (Electrocap International) distributed according to the standard International 10-20 system (Jasper, 1958) and referenced to the nose. EEG activity was amplified with a band-pass between $0.1 \mathrm{~Hz}$ and $200 \mathrm{~Hz}$ (BrainAmps DC amplifier, Brain Products GmbH, Munich, Germany), continuously digitised at a sampling rate of $500 \mathrm{~Hz}$, and refiltered offline at $30 \mathrm{~Hz}$ low pass. The electrode impedance was set below $5 \mathrm{k} \Omega$. Epochs ranged from $-100 \mathrm{~ms}$ to $1000 \mathrm{~ms}$ after the onset of the critical article. Artifacts were automatically rejected using the procedure implemented in Brain Analyzer 2.0 (differences in values $200 \mu \mathrm{v}$ in $200 \mathrm{~ms}$ intervals, and amplitudes of $+/-100 \mu \mathrm{v}$ ), resulting in $8.7 \%$ and $7.1 \%$ of rejected trials in the expected and unexpected condition, respectively. Baseline correction was performed in reference to pre-stimulus activity (100; $0 \mathrm{~ms}$ ) and individual averages were digitally re-referenced to the average of the mastoid electrodes. The ERP data were quantified by calculating the mean voltage amplitudes. Based on previous studies, we expected a negativity peaking around $400 \mathrm{~ms}$ (Foucart et al., 2014; Wicha, Moreno, et al., 2003), potentially preceded by an early differential (Van Berkum et al., 2005). Visual inspection of the grand mean (Figure 1) revealed an early and a later negativity which were confirmed using a 2 ms-by- 2 ms 
paired $t$-tests for the difference between the Expected and Unexpected conditions. Unstable differences (remaining below $p=.05$ for less than $30 \mathrm{~ms}$ ) were discarded (Rugg, Doyle, \& Wells, 1995). Subsequently, analyses were conducted on the 200-280 ms and 450-900 ms these time-windows ${ }^{1}$. ANOVAs were conducted with the factors Expectation (expected vs. unexpected) and Region (Frontal, Central and Parietal). Regions were defined as Frontal (F7, F3, FC5, FC1, Fz, F8, F4, FC6, FC2), Central (T3, C3, CP5, CP1, Cz, T4, C4, CP6, CP2) and Parietal regions (T5, P3 P1, O1, Pz, O2, P2, T6, P4) to observe the overall distribution of the effect. The Greenhouse-Geisser correction (Greenhouse \& Geisser, 1959) was applied to all repeated measures with greater than one degree of freedom; in this case, the corrected $p$ value is reported.

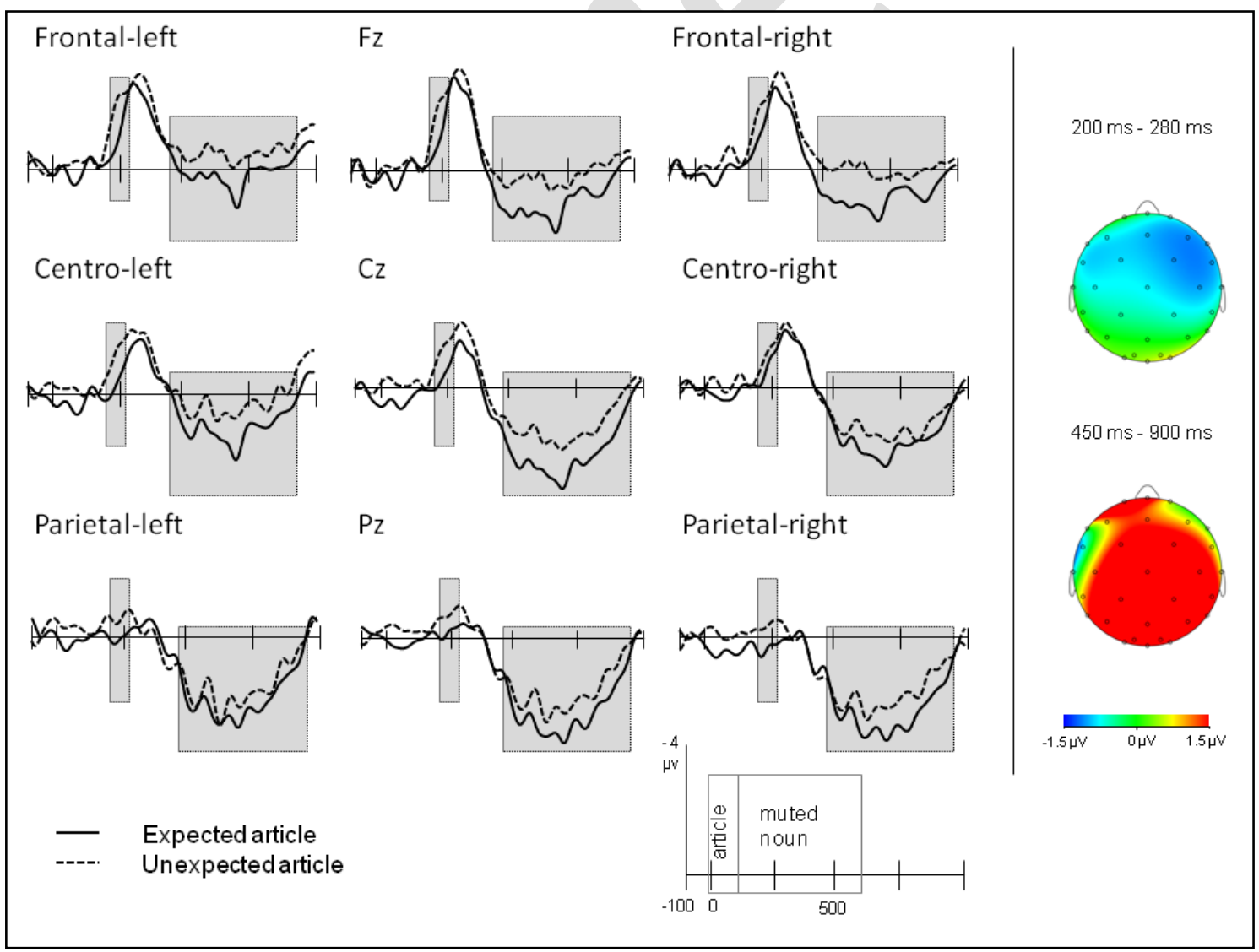

\section{Figure captions}

Figure 1. Left panel: Event-related potential results for the critical article of the sentence. Time zero indicates the presentation of the article. Black lines depict ERPs 
measured for expected articles; dotted lines depict ERPs measured for unexpected articles. ERPs measured over single channels at midline sites (Fz, Cz, Pz) and averaged channels at Frontal left (F7, F3, FC5, FC1), Frontal right (F8, F4, FC6, FC2), Central left (T3, C3, CP5, CP1), Central right (T4, C4, CP6, CP2), Parietal left (T5, P3, P1, O1) and Parietal right (O2, P2, T6, P4) regions. The grey rectangles represent the timewindows analysed. Negativity is plotted up. Right panel: Topographic distributions of the difference between the expected and unexpected conditions across the 200-280 ms and 450-900 ms time-windows.

\section{Lexical recognition task}

Following the listening phase, participants were presented with the 52 "expected" words, 52 “unexpected” words, 52 “old” words (from the filler sentences) and 52 "new” words (equally matched in length and frequency with the words from the other conditions). The difference between "new" words and "unexpected" words is that the latter could have been potentially expected from the context. Indeed, the cloze probability of "unexpected" words when the unexpected article was presented (Context 2, see Table 2) was moderate (0.38), as assessed by a cloze probability test in which participants (who did not take part in the experiment) had to complete sentences that included the unexpected article by the first word that came to their mind. This suggests that the unexpected continuation was something that perfectly fit in the context and that could have been somehow expected (to a lesser extent than "expected” words), which makes the difference between "unexpected" words and "new" words.

Participants were presented with all the words, independently of the list they received in the listening phase (see Table 2). This was done to examine whether the presentation of 
an unexpected article would reduce the memory trace of a word expected from the context; for example, looking at Table 2, whether the word "tesoro" would be expected to the same extent from sentence Context 1 (expected article) than from Context 2 (unexpected article). Participants were instructed to indicate whether they had heard the word during the listening phase using the yes-no keys. To balance the number of yes-no answers, an extra 52 words were selected from the sentences heard in the listening phase (not analysed). All the words were recorded individually by the same speaker and presented auditorily using E-prime. Participant's answer triggered a fixation cross preceding the following word. 
Table 2. Design of the lexical recognition task in relation to the sentences heard in the listening phase.

Sentence presented

in the listening phase
Word presented

in the lexical recognition task answer to the

question:

'Did you hear

this word?'

Yes No

Context 1 (Expected article):

El pirata tenía el mapa secreto, pero tesoro [masc] gruta [fem]

nunca encontró $\underline{\text { el }}[\mathrm{masc}] \mathrm{XXXX}$ que $(\mathrm{N}=26) \quad(\mathrm{N}=26)$

X

buscaba.*

Context 2 (Unexpected article):

El pirata tenía el mapa secreto, pero gruta [fem] tesoro [masc]

nunca encontró $\underline{\underline{l a}}$ [fem] $X X X X$ que $(\mathrm{N}=26) \quad(\mathrm{N}=26)$

buscaba.*

\section{Filler sentences}

Tengo que comprar mi billete para ir billete

$(\mathrm{N}=52)$

a Londres. *

galleta (biscuit)

$(\mathrm{N}=52)$

\footnotetext{
*The pirate had the secret map, but he never found the treasure/the cave he was looking for.

*I need to buy my ticket to go to London.
} 
Results

EEG

The ANOVAs performed on the 200-280 ms time-window revealed a significant main effect of Expectation $(F(1,19)=4.78, M S E=20.86, p=.04)$ and a main effect of Region $(F(2,38)=13.59, M S E=17.59, p<.001)$. The two factors did not interact $(F(2,38)=$ 0.24, MSE $=0.14, p=.79$ ). In the $450-900 \mathrm{~ms}$ time-window, the main effect of Expectation reached significance $(F(1,19)=5.15, M S E=15.84, p=.03)$ and so did the factor Region $(F(2,38)=16.92, M S E=46.94, p<.001)$. The interaction Expectation $\mathrm{x}$ Region was not significant $(F(2,38)=0.53, M S E=0.37, p=.59)$. In both time-windows the results show a deflection significantly more negative for unexpected than expected articles.

\section{Lexical recognition task}

Results are presented in terms of hits and false alarms for each condition in Table $3^{2}$ (note that to balance the number of items across conditions only 26 out of the 52 stimuli of the conditions "Old" and "New" were randomly selected for the analyses). Analyses ( $t$-test) were conducted on the percentage of words that were assessed as not heard during the listening phase (i.e., "misses" for the "Old" condition and "correct rejections" for the other conditions). 
Table 3. Results of the lexical recognition task presented in terms of percentages of hits and false alarms for each condition

\begin{tabular}{lcc}
\hline Conditions (items per condition, N=26) & Hits & False alarms \\
\hline "Old” & $52 \%$ & \\
"New” & $25 \%$ \\
"Expected" (Context 1) & $49 \%$ \\
"Unexpected” (Context 1) & $33 \%$ \\
"Expected" (Context 2) & $40 \%$ \\
"Unexpected" (Context 2) & $28 \%$ \\
\hline
\end{tabular}

Since we had clear predictions, we performed $t$-tests on the relevant conditions. We took the "Old" vs. "New" conditions as the baseline comparison (since they were the only conditions contrasting words that were actually heard during the listening phase against words that were never presented). Analyses revealed that participants were not performing the task randomly $\left(d^{\prime}=0.83\right)$ and that they assessed "new" words as not heard more often than "old" words $(t(19)=8.76, p<.001)$. As predicted, the conditions “Old" and "Expected" were not significantly different $(t(19)=0.59, p=.56)$ but the condition "Unexpected" was significantly different from the "Old" condition $(t(19)=$ 9.08, $p<.001)$ and from the "Expected" condition $(t(19)=5.09, p<.001)$. Finally, “expected” words that were preceded by sentence Context 2 (unexpected article) were assessed as not heard significantly more often than when preceded by Context 1 (expected article) $(t(19)=2.22, p=.04)$. These results demonstrated that participants falsely answered they had heard (muted) "expected” words significantly more often than "unexpected" words in the listening phase, as revealed by the larger number of correct rejection for "unexpected” than "expected” words. Interestingly, the results also 
show that the presence of an unexpected article (Context 2) seems to reduce the context effects on upcoming words, as suggested by the larger number of correct rejections for expected words preceded by sentence Context 2 than for expected words preceded by Context 1. In other words, the expectation of the word 'tesoro' (treasure) is reduced when the sentence context contains the article "la" (instead of "el") since it does not match in gender and therefore renders 'tesoro' an impossible candidate for the continuation of the sentence.

\section{Discussion}

In the present paper, we report an ERP study investigating anticipation processes in speech comprehension and their effect on memory trace in posterior lexical recognition. We presented participants with highly-constrained audio sentences in Spanish triggering an expected noun. To detect the presence of anticipation effects in speech, we looked at the effects on the article preceding the critical noun. The article either matched the gender of the expected noun or not. Crucially, to avoid any overlap with the potential effects generated by the noun, the critical noun was muted. The main observation of the study was the presence of an ERP differential elicited by expected and unexpected articles. The results showed an early negativity (200-280 ms) followed by a later negativity (450-900 ms), both more negative for unexpected than for expected articles. The experimental manipulation also enabled us to examine whether anticipation processes have an impact on memory recollection of a word that is not actually heard; following the listening phase, we conducted a lexical recognition task. The lexical recognition task revealed that, although both "expected " and "unexpected” nouns were muted during the listening phase, "expected” nouns were falsely recognised as having been heard significantly more often than "unexpected" words, and as often as "old" 
nouns that were previously presented. The implications of these results are discussed below.

The main contribution of our study is the results of the ERPs associated to expected and unexpected articles; these are in line with previous studies showing that sentence context can be used to predict upcoming words and their features during sentence comprehension (DeLong et al., 2005; Foucart et al., 2014; Martin et al., 2013; Otten et al., 2007; Van Berkum et al., 2005; Wicha et al., 2004; Wicha, Moreno, et al., 2003). Indeed, as previously reported, an ERP differential was observed between the articles that matched the gender of the expected nouns and those that did not. This observation demonstrates that when the context is sufficiently constraining, anticipation processes allow a word to be predicted and its features to agree with associated words (e.g., articles) even before it is presented. This suggests incremental sentence processing, which facilitates fluent conversation but also allows detection of a misleading prediction even before the noun comes along.

As reported, the results show that articles that mismatched with the gender of the expected noun elicited an early negativity at 200-280 ms and a later negativity at 450$900 \mathrm{~ms}$. These results offer two potential interpretations. The first possibility is that the two effects are not actually distinct and that the first negativity is part of an early N400like effect (the N400 has been observed as early as 200-300 ms in speech comprehension; Van Petten et al., 1999). The second possibility is that the two effects are distinct and that, as proposed in previous auditory studies, spoken words incongruent with the preceding context provoke a negative shift around $200 \mathrm{~ms}$ compared to words that are congruent (Connolly, Phillips, Stewart, \& Brake, 1992; Groppe et al., 2010; Hagoort \& Brown, 2000; van den Brink, Brown, \& Hagoort, 2001, 2006; van den Brink \& Hagoort, 2004). Hence, the effects we observed could be a first 
negativity reflecting a conflict at phonological level related to the expected word, followed by a delayed N400-like effect. Delayed N400 effects (compared to the classic N400 to spoken words; Hagoort \& Brown, 2000; Van Petten, Coulson, Rubin, Plante, \& Parks, 1999) have been observed in studies investigating phoneme restoration using tones or coughs (Groppe et al., 2010; Sivonen, Maess, Lattner, \& Friederici, 2006); the present manipulation of muting the noun may have affected processing in a similar way. The present study did not include a manipulation allowing us to tell apart these two alternatives (see Groppe et al., 2010, for a discussion).

Our results replicate those previously reported in studies investigating word anticipation in auditory modality. Wicha et al. (Wicha, et al., 2003) and Otten (Otten et al., 2007) also observed a negativity. Note, however, that inconsistent predictions have also been reflected by a positivity; Van Berkum and colleagues reported an early positivity between 50-250 ms (Van Berkum et al., 2005) in the left-posterior electrodes from the onset of the inflection of the adjective preceding the critical noun in Dutch sentences. This study differs from ours regarding the language, the word class and the polarity of the effect; it is still unclear why the effects observed across studies vary in polarity and timing, but crucially, all studies report an ERP differential for words inconsistent with the prediction built up from the sentence context. Importantly, Van Berkum and colleagues observed an early effect (Experiment 1) and ruled out the possibility of it being an artifact in a subsequent control experiment (Experiment 2); our results are consistent with theirs and confirm that prediction-inconsistent words trigger effects observed earlier than the N400 time-window.

Note as well that, similarly to other studies reporting anticipation effects on the article preceding (un)-expected noun (DeLong et al., 2005; Foucart et al., 2014; Martin et al., 2013; Wicha, Moreno, et al., 2003), the negativity observed does not exactly 
resemble the classic N400; this is likely to be due to the fact that the N400 is generally associated to lexical integration of content words; here (as well as in the other studies) we looked at processing of function words, which also involves syntactic processing (gender agreement with the expected word), usually indicated by a modulation of the P600 (Barber \& Carreiras, 2005; Foucart \& Frenck-Mestre, 2010; Hagoort \& Brown, 1999). This may account for the untypical morphology of the N400-like negativity we observe.

To sum up, the contribution of the ERP experiment is relevant as it confirms the previous indications that sentence context effects influence spoken word recognition even before a word is presented (Van Berkum et al., 2005; Wicha, Bates, et al., 2003)

The second contribution of our study refers to the effects of anticipatory processes on lexical recognition. Recall that the lexical recognition task conducted after the main experiment allowed us to explore the recollection of words that were predicted but were never heard. The results showed that, although neither the "expected" nor the "unexpected” words were actually heard during the listening phase, "expected” words were wrongly assessed as "heard" significantly more often than "unexpected" words, and as often as "old" words (that were actually presented). Moreover, the presence of an unexpected article in the sentence context seems to reduce the context effects on upcoming words. In other words, it seems that anticipation processes allow a memory trace of a word to be created prior presentation. This is in line with studies showing context effects on the processing of missing or degraded speech (Bendixen, Scharinger, Strauß, \& Obleser, 2014; Groppe et al., 2010; Sivonen et al., 2006; Sohoglu, Peelle, Carlyon, \& Davis, 2012; Windmann, 2004). For instance, studies have shown that a word can be perceived as "intact” even though a phoneme is missing if it is preceded by an informative context; this phenomenon called phoneme restoration refers to the fact 
that people can falsely perceive or "hallucinate" a phoneme that is missing (Groppe et al., 2010; Sivonen et al., 2006; Warren, 1970), which supports the idea that top-down information is used during speech processing. Our results then support the idea advanced by Van Berkum and colleagues that upcoming words are in a way "hallucinated" and that the word recognition system benefits from lexical pre-activation (Van Berkum et al., 2005). Following Jackendoff's framework (Jackendoff, 2002) which envisages lexical representation as a connection between phonology, syntax and semantics, Van Berkum and colleagues (Van Berkum et al., 2005) proposed that anticipation processes take into account the phonological, syntactic and semantic constraints provided by the context to adjust the prediction of upcoming words as the sentence unfolds. The fact that (muted) "expected" words that were preceded by a mismatching article were not hallucinated to the same extent as when preceded by a matching article is in line with this proposal. It seems that comprehenders anticipate upcoming words and their features, and if they encounter prediction-inconsistent information they are able to rapidly “cancel out” or at least, reduce their prediction.

This proposal converges with theories of perception and sensory predictability which argue that the brain creates a template of upcoming sensory units using a forward model and that this pattern is then compared to the sensory input. In other words, topdown information is used to generate a prediction and bottom-up information detect whether the prediction is correct (Arnal \& Giraud, 2012; Friston, 2005; Wacongne, Changeux, \& Dehaene, 2012). If no input is actually presented and thus no bottom-up information can be contrasted to top-down information, the pattern of brain activity provoked by the template resembles (but is not identical) that of the actual sensory input (see for example, SanMiguel, Widmann, Bendixen, Trujillo-Barreto, \& Schröger, 2013). Following this reasoning, we could account for the present results with a 
tentative proposal that a template of a word was generated by the brain based on topdown information provided by the sentence context, since this template could not be compared with the bottom-up information provided by the word upon presentation (since it was muted), only the template remains, resulting in a "hallucination" of the word. Note, however, as underlined by SanMiguel and colleagues, the pattern of activity for the template is not exactly similar to that of the actual input, and similarly, we believe the memory trace for the hallucinated word would not be exactly similar to that of an actually presented word. Although this proposal requires further research, it accounts for our results that go against models of word recognition that discard the idea of prediction and support a bottom-up view (Marslen-Wilson, 1987, 1989; Norris, 1994). Furthermore, the overall results reported here do not fit with the assumption of “passive resonance” processes (Kuperberg et al., 2011; Myers \& O’Brien, 1998; Paczynski \& Kuperberg, 2012) and are more in line with the "active lexical prediction” (DeLong, Urbach, \& Kutas, 2005; Neely, 1977).

Before concluding, we want to point out some shortcomings. First, we cannot totally exclude that cues about the muted target word might have been available to participants despite our efforts to minimize the potential effects of coarticulation on article offset when splicing the sentences. Second, in the Lexical Recognition task, "Old” words and "Expected" words were not the exact same words. Adding this condition to the design would have been an interesting comparison, and should be indeed included in future experiments. Finally, the results we report are consistent with previous studies and our hypothesis, however, increasing the number of items and participants may reveal effects that could not be detected in the present study.

To conclude, in the present study we investigated anticipation processes in speech comprehension and their effect on lexical recognition. The results confirm previous 
indications that anticipation processes are at play during speech processing as sentence context effects are observed even before a word is presented. The results also indicate that anticipation processes allow a word to be "hallucinated", which implies that comprehenders do not rely only on integration processes during speech comprehension, despite the fact that listening pace is faster than reading pace. The results support a topdown view of speech processing. 


\section{Acknowledgements}

This work was supported by grants from the Spanish Government (PSI2011-23033, CONSOLIDER-INGENIO2010 CSD2007-00048, ECO2011-25295, and ECO201009555-E), from the Catalan Government (SGR 2009-1521) and from the 7th Framework Programme (AThEME 613465). We would like to thank Ziggy Campbell for his technical advice on the preparation of the audio stimuli and Dr Clara Martin for her useful comments. 
References

Arnal, L. H., \& Giraud, A.-L. (2012). Cortical oscillations and sensory predictions. Trends in Cognitive Sciences, 16(7), 390-8. doi:10.1016/j.tics.2012.05.003

Barber, H., \& Carreiras, M. (2005). Grammatical gender and number agreement in Spanish: an ERP comparison. Journal of Cognitive Neuroscience, 17(1), 137-53. doi:10.1162/0898929052880101

Bendixen, A., Scharinger, M., Strauß, A., \& Obleser, J. (2014). Prediction in the service of comprehension: modulated early brain responses to omitted speech segments. Cortex; a Journal Devoted to the Study of the Nervous System and Behavior, 53, 9-26. doi:10.1016/j.cortex.2014.01.001

Coane, J. H., \& Balota, D. A. (2010). Repetition priming across distinct contexts: effects of lexical status, word frequency, and retrieval test. Quarterly Journal of Experimental Psychology (2006), 63(12), 2376-98. doi:10.1080/17470211003687546

Connolly, J. F., Phillips, N. A., Stewart, S. H., \& Brake, W. G. (1992). Event-related potential sensitivity to acoustic and semantic properties of terminal words in sentences. Brain and Language, 43(1), 1-18. Retrieved from http://www.ncbi.nlm.nih.gov/pubmed/1643505

Corley, M., MacGregor, L. J., \& Donaldson, D. I. (2007). It's the way that you, er, say it: hesitations in speech affect language comprehension. Cognition, 105(3), 65868. doi:10.1016/j.cognition.2006.10.010

Davis, C. J., \& Perea, M. (2005). BuscaPalabras: a program for deriving orthographic and phonological neighborhood statistics and other psycholinguistic indices in Spanish. Behavior Research Methods, 37(4), 665-71. Retrieved from http://www.ncbi.nlm.nih.gov/pubmed/16629300

DeLong, K. A., Urbach, T. P., \& Kutas, M. (2005). Probabilistic word pre-activation during language comprehension inferred from electrical brain activity. Nature Neuroscience, 8(8), 1117-21. doi:10.1038/nn1504

Federmeier, K. D., \& Kutas, M. (1999). A rose by any other name: Long-term memory structure and sentence processing. Journal of Memory and Language, 41, 469-495.

Federmeier, K. D., Wlotko, E. W., De Ochoa-Dewald, E., \& Kutas, M. (2007). Multiple effects of sentential constraint on word processing. Brain Research, 1146, 75-84. doi:10.1016/j.brainres.2006.06.101

Finnigan, S., Humphreys, M. S., Dennis, S., \& Geffen, G. (2002). ERP “old/new” effects: memory strength and decisional factor(s). Neuropsychologia, 40(13), 2288-304. Retrieved from http://www.ncbi.nlm.nih.gov/pubmed/12417459

Foucart, A., \& Frenck-Mestre, C. (2010). Grammatical gender processing in L2: Electrophysiological evidence of the effect of L1-L2 syntactic similarity. 
Bilingualism: Language and Cognition, 14(03), 379-399.

doi:10.1017/S136672891000012X

Foucart, A., Martin, C. D., Moreno, E. M., \& Costa, A. (2014). Can Bilinguals See It Coming? Word Anticipation in L2 Sentence Reading. Journal of Experimental Psychology: Learning, Memory, and Cognition.

Friston, K. (2005). A theory of cortical responses. Philosophical Transactions of the Royal Society of London. Series B, Biological Sciences, 360(1456), 815-36. doi:10.1098/rstb.2005.1622

Greenhouse, S. W., \& Geisser, S. (1959). On methods in the analysis of profile data. Psychometrika, 24, 95-112.

Groppe, D. M., Choi, M., Huang, T., Schilz, J., Topkins, B., Urbach, T. P., \& Kutas, M. (2010). The phonemic restoration effect reveals pre-N400 effect of supportive sentence context in speech perception. Brain Research, 1361, 54-66. doi:10.1016/j.brainres.2010.09.003

Hagoort, P., \& Brown, C. M. (1999). Gender electrified: ERP evidence on the syntactic nature of gender processing. Journal of Psycholinguistic Research, 28(6), 715-28. Retrieved from http://www.ncbi.nlm.nih.gov/pubmed/10510866

Hagoort, P., \& Brown, C. M. (2000). ERP effects of listening to speech: semantic ERP effects, 38, 1518-1530.

Jackendoff, R. (2002). Foundations of language. New York: Oxford University Press.

Jasper, H. H. (1958). The ten twenty electrode system of the International Federation. Electroencephalography and Clinical Neurophysiology, 5, 196-214.

Kuperberg, G. R., Paczynski, M., \& Ditman, T. (2011). Establishing causal coherence across sentences: an ERP study. Journal of Cognitive Neuroscience, 23(5), 1230 46. doi:10.1162/jocn.2010.21452

Lau, E. F., Holcomb, P., \& Kuperberg, G. R. (2013). Dissociating N400 effects of prediction from association in single-word contexts. Journal of Cognitive Neuroscience, 25(3), 484-502. doi:10.1162/jocn_a_00328

MacGregor, L. J., Corley, M., \& Donaldson, D. I. (2010). Listening to the sound of silence: disfluent silent pauses in speech have consequences for listeners. Neuropsychologia, 48(14), 3982-92. doi:10.1016/j.neuropsychologia.2010.09.024

Marslen-Wilson, W. D. (1973). Linguistic structure and speech shadowing at very short latencies. Nature, 244(5417), 522-523.

Marslen-Wilson, W. D. (1987). Functional parallelism in spoken word-recognition. Cognition, 25(1-2), 71-102. Retrieved from http://www.ncbi.nlm.nih.gov/pubmed/3581730 
Marslen-Wilson, W. D. (1989). Access and integration: Projecting sound onto meaning. In W. D. Marslen-Wilson (Ed.), Lexical representation and process (pp. 3-24). Cambridge, MA: MIT Press.

Martin, C. D., Thierry, G., Kuipers, J.-R., Boutonnet, B., Foucart, A., \& Costa, A. (2013). Bilinguals reading in their second language do not predict upcoming words as native readers do. Journal of Memory and Language, 69(4), 574-588. doi:10.1016/j.jml.2013.08.001

Myers, J. L., \& O’Brien, E. J. (1998). Accessing the discourse representation during reading. Discourse Processes, 26, 131-157.

Navarro, T. (1950). Manual de pronunciación española. Madrid: Consejo Superior de Investigaciones Científicas.

Neely, J. H. (1977). Semantic priming and retrieval from lexical memory: roles of inhibitionless spreading activation and limited-capacity attention. Journal of Experimental Psychology General, 106, 226-54.

Norris, D. (1994). Shortlist: A connectionist model of continuous speech recognition. Cognition, 52, 189-234.

Otten, M., Nieuwland, M. S., \& Van Berkum, J. J. A. (2007). Great expectations: specific lexical anticipation influences the processing of spoken language. $B M C$ Neuroscience, 8, 89. doi:10.1186/1471-2202-8-89

Paczynski, M., \& Kuperberg, G. R. (2012). Multiple Influences of Semantic Memory on Sentence Processing: Distinct Effects of Semantic Relatedness on Violations of Real-World Event/State Knowledge and Animacy Selection Restrictions. Journal of Memory and Language, 67(4), 426-448. doi:10.1016/j.jml.2012.07.003

Pickering, M. J., \& Garrod, S. (2007). Do people use language production to make predictions during comprehension? Trends in Cognitive Sciences, 11(3), 105-10. doi:10.1016/j.tics.2006.12.002

Rayner, K., \& Clifton, C. (2009). Language processing in reading and speech perception is fast and incremental: implications for event-related potential research. Biological Psychology, 80(1), 4-9. doi:10.1016/j.biopsycho.2008.05.002

Riding, R. J., \& Vincent, D. J. T. (1980). Listening comprehension: the effects of sex, age, passage structure and speech rate. Education Review, 32(3), 418-436.

Rugg, M. D., Doyle, M. C., \& Wells, T. (1995). Word and nonword repetition withinand across-modality: an event-related potential study. Journal of Cognitive Neuroscience, 7(2), 209-27. doi:10.1162/jocn.1995.7.2.209

SanMiguel, I., Widmann, A., Bendixen, A., Trujillo-Barreto, N., \& Schröger, E. (2013). Hearing silences: human auditory processing relies on preactivation of soundspecific brain activity patterns. The Journal of Neuroscience : The Official Journal 
of the Society for Neuroscience, 33(20), 8633-9. doi:10.1523/JNEUROSCI.582112.2013

Schneider, W., Eschman, A., \& Zuccolotto, A. (2002a). E-Prime Reference Guide. Pittsburgh: Psychology Software Tools Inc.

Schneider, W., Eschman, A., \& Zuccolotto, A. (2002b). E-Prime User's Guide. Pittsburgh: Psychology Software Tools Inc.

Sivonen, P., Maess, B., Lattner, S., \& Friederici, A. D. (2006). Phonemic restoration in a sentence context: evidence from early and late ERP effects. Brain Research, 1121(1), 177-89. doi:10.1016/j.brainres.2006.08.123

Sohoglu, E., Peelle, J. E., Carlyon, R. P., \& Davis, M. H. (2012). Predictive top-down integration of prior knowledge during speech perception. The Journal of Neuroscience : The Official Journal of the Society for Neuroscience, 32(25), 844353. doi:10.1523/JNEUROSCI.5069-11.2012

Van Berkum, J. J. A., Brown, C. M., Zwitserlood, P., Kooijman, V., \& Hagoort, P. (2005). Anticipating upcoming words in discourse: evidence from ERPs and reading times. Journal of Experimental Psychology. Learning, Memory, and Cognition, 31(3), 443-67. doi:10.1037/0278-7393.31.3.443

Van den Brink, D., Brown, C. M., \& Hagoort, P. (2001). Electrophysiological evidence for early contextual influences during spoken-word recognition: N200 versus N400 effects. Journal of Cognitive Neuroscience, 13(7), 967-85. doi:10.1162/089892901753165872

Van den Brink, D., Brown, C. M., \& Hagoort, P. (2006). The cascaded nature of lexical selection and integration in auditory sentence processing. Journal of Experimental Psychology. Learning, Memory, and Cognition, 32(2), 364-72. doi:10.1037/02787393.32.3.364

Van den Brink, D., \& Hagoort, P. (2004). The influence of semantic and syntactic context constraints on lexical selection and integration in spoken-word comprehension as revealed by ERPs. Journal of Cognitive Neuroscience, 16(6), 1068-84. doi:10.1162/0898929041502670

Van Petten, C., Coulson, S., Rubin, S., Plante, E., \& Parks, M. (1999). Time course of word identification and semantic integration in spoken language. Journal of Experimental Psychology. Learning, Memory, and Cognition, 25(2), 394-417. Retrieved from http://www.ncbi.nlm.nih.gov/pubmed/10093207

Wacongne, C., Changeux, J.-P., \& Dehaene, S. (2012). A neuronal model of predictive coding accounting for the mismatch negativity. The Journal of Neuroscience: The Official Journal of the Society for Neuroscience, 32(11), 3665-78. doi:10.1523/JNEUROSCI.5003-11.2012 
Warren, R. M. (1970). Perceptual restoration of missing speech sounds. Science (New York, N.Y.), 167(3917), 392-3. Retrieved from

http://www.ncbi.nlm.nih.gov/pubmed/5409744

Wicha, N. Y. Y., Bates, E. A., Moreno, E. M., \& Kutas, M. (2003). Potato not Pope: human brain potentials to gender expectation and agreement in Spanish spoken sentences. Neuroscience Letters, 346(3), 165-168. doi:10.1016/S03043940(03)00599-8

Wicha, N. Y. Y., Moreno, E. M., \& Kutas, M. (2003). Expecting gender: an event related brain potential study on the role of grammatical gender in comprehending a line drawing within a written sentence in Spanish. Cortex; a Journal Devoted to the Study of the Nervous System and Behavior, 39(3), 483-508. Retrieved from http://www.pubmedcentral.nih.gov/articlerender.fcgi?artid=3392191\&tool=pmcent rez\&rendertype $=$ abstract

Wicha, N. Y. Y., Moreno, E. M., \& Kutas, M. (2004). Anticipating words and their gender: an event-related brain potential study of semantic integration, gender expectancy, and gender agreement in Spanish sentence reading. Journal of Cognitive Neuroscience, 16(7), 1272-88. doi:10.1162/0898929041920487

Windmann, S. (2004). Effects of sentence context and expectation on the McGurk illusion. Journal of Memory and Language, 50(2), 212-230.

doi:10.1016/j.jml.2003.10.001 


\section{Appendix 1}

Complete list of the original sentences in Spanish with literal translation in English. Expected and unexpected critical nouns (muted during the listening phase) are underlined. ${ }^{3}$

Juan tiene manos de músico ya que toca el piano/la guitarra a menudo.

Juan has musician's hands since he plays the piano/the guitar often.

Al final, el héroe se acerca a la mujer y le da un beso/una caricia con afecto.

At the end, the hero gets closer to the woman and gives her a kiss/a caress with affection.

Quiero pedir una cita pero nadie ha cogido el teléfono/la llamada en toda la mañana.

I want to make an appointment but nobody has picked up the phone/the call in the whole day.

Estoy cansado, para despertar me voy a tomar un caféluna bebida con mucho azúcar.

I'm tired, to wake up I am going to have a coffee/a beverage with lots of sugar.

Las diagonales de un cuadrado se cruzan en el centro/la mitad precisamente.

The diagonals of a square cross in the centre/the middle precisely.

Ayer fui a la biblioteca para devolver un libro/una peli en francés.

Yesterday I went to the library to return a book/a film in French.

En Barcelona, la Boqueria es un mercado/una atracción muy turístico.*

In Barcelona, the Boqueria is a market/an attraction very touristic.

Mis padres tienen una casa grande y pueden aparcar los dos coches en el garaje/la entrada sin problema. 
My parents have a big house and can park both cars in the garage/the driveway without any problem.

El ingrediente básico del brownie es el chocolate/la harina según la receta.

The basic ingredient of the brownie is the chocolate/the flour according to the recipe.

Tengo un móvil nuevo, para probarlo te envié un mensaje/una foto hace un momento.

I have got a new mobile; to test it I sent you a message/a photo a moment ago.

Después de cenar, veo las noticias en la tele/el móvil y luego voy a dormir.

After dinner, I watch the news on the TV/the mobile and then I go to bed.

En las grandes ciudades, el medio de transporte más rápido es el metro/la bici seguramente.

In big cities, the fastest means of transport is the metro/the bike for sure.

Le encanta la música por eso su amiga le ofreció una entradapara ir a un concierto/una fiesta techno.

He loves music so his friend offered him a ticket to go to a concert/a party techno.

Después del accidente no puede recordar nada porque ha perdido la memoria/el juicio por completo.

Since the accident he cannot remember anything because he has lost the memory/his mind completely.

Le gusta mucho la música rock, toca la batería/el teclado muy bien.

He really likes rock music, he plays the drums/the keyboard very well.

El pirata tenía el mapa secreto, pero nunca encontró el tesoro/la gruta que buscaba.

The pirate had the secret map but he never found the treasure/the cave he was looking for.

Si no se afeita con regularidad le crece mucho la barba/el pelo y el bigote.

If he does not shave regularly grow a lot the beard/the hair and the moustache. 
Estoy sucio, he sudado mucho en el gimnasio, voy a tomar una ducha/un baño de inmediato.

I am dirty, I have sweat a lot at the gym, I am going to have a shower/a bath right now.

En verano me baño en casa de mis vecinos, que tienen una piscina/un estanque bastante grande.

In summer, I bath at my neighbour's, they have a swimming pool/a pond fairly big.

Cuando estaba bastante cerca del animal, sacó su cámara e hizo una foto/un vídeo rápidamente.

When he was close enough to the animal, he took out his camera and made a picture/a video quickly.

El rey llevaba en la cabeza una corona/un sombrero antigua.*

The king had on his head a crown/a hat old.

Le gusta mucho el whisky, por eso le regalamos una botella/un vaso especial de Escocia.

He very much likes whisky, for this reason we offered him a bottle/a glass special from Scotland.

La niña no pesa nada, es ligera como una pluma/un pelo, de verdad.

The girl does not weigh anything, she is as light as a feather/a hair, really.

En general, el té se bebe en una taza/un vaso de cristal.

In general, tea is drunk from a cup/a glass of glass.

Los niños hacen castillos de arena en la playa/el parque durante el verano.

The children make sandcastles on the beach/in the park in summer.

El pino es un árbol y la rosa es una flor/un arbusto con espinas.

The pine is a tree and the rose is a flower/bush with thorns. 
Antes de cocinar el pollo, hay que precalentar el horno/la plancha durante diez minutos.

Before cooking the chicken, one has to pre-heat the oven/the pan for ten minutes.

A mi abuela le encanta acariciar los animales, así que le hemos comprado un gato/una cabra por Navidad.

My grand-mother loves stroking animals, for this reason we bought her a cat/a goat for Christmas.

Uno de los órganos humanos más importante es el corazón/la lengua por supuesto.

One of the most important of the human organs is the heart/the tongue, of course.

De los cuatro elementos, el agua es el que puede apagar el fuego/la llama de la manera más eficiente.

Of the four elements, water is that that can extinguish the fire/the flame in the most efficient way.

El jueves es su cumpleaños, tenemos que comprarle un regalo/una tarta mañana.

On Thursday it’s his birthday, we have to buy him a present/a cake tomorrow.

Antes de enviar una carta tienes que poner un sello/una dirección en el sobre.

Before sending a letter, you have to put a stamp/an address on the envelope.

El billar es un juego y el squash es un deporte/una actividad muy físico.*

Pool is a game and squash is a sport/an activity very physical.

La niña tiene lápices de colores nuevos y ha hecho un dibujo/una ilustración para su madre.

The girl has new colour pencils and she made a drawing/an illustration for her mother. Estaba cansada de cocinar de pie por eso se sentó en la silla/el taburete un momentito. She was tired of cooking standing up so she sat down on the chair/the stool for a little while. 
Para cortar la carne se necesita un cuchillo/una pinza de metal.

To cut the meat one needs a knife/tongs of metal.

A mi padre le gusta estar al tanto de la información, por eso, cada día lee el periódico/la revista de economía.

My father likes to keep up to date about the news, so every day he reads the newspaper/the review of economics.

Para encender el cigarrillo usó un mechero/una cerilla y se quemó.

To light his cigarette, he used a lighter/a match and he burnt himself.

Nunca sé dónde poner mi móvil y mi cartera, tengo que comprarme un bolso/una mochila que combine con todo.

I never know where to put my mobile and my wallet, I need to buy myself a handbag/a backpack that matches everything.

Desde su sofá, mi abuela espía lo que pasa fuera mirando por la ventana/el balcón todo el día.

From her sofa my grand-mother spies on what is happening outside through the window/the balcony the whole day.

Después de bañarme, me seco con una toalla/un albornoz de algodón.

After bathing, I dry myself with a towel/a dressing gown of cotton.

Ayer las carreteras de montaña fueron cerradas por la nievelel viento en los Pirineos. Yesterday the roads in the mountain were close because of the snow/the wind in the Pyrenees.

La casa está cerrada, para abrir necesitamos la llave/el código pero no sé quien la tiene.

The house is locked, to open we need the key/the code but I don't know who has it. 
Acabo de salir de la casa y no recuerdo si he cerrado la puerta/el gas cuando me he ido.

I just gone out of home and I can't remember if I locked the door/the gas when I left.

La ropa está sucia, ponla en la lavadora/el cesto por favor.

The clothes are dirty, put them in the washing machine/basket, please.

Para pagar por internet en esta web se necesita una tarjeta/un código válida.*

To pay by internet on this webpage one needs a card/a code valid.

En verano es importante protegerse, el sol puede hacer lesiones en la piel/el cuerpo y el cabello.

In summer it's important to be protected, the sun can make lesions on the skin/the body and the hair.

Mi novio es músico y me ha escrito una canción/un poema muy romántica.*

My boy-friend is musician and he wrote me a song/a poem very romantic.

Pinocho es una marioneta y Barbie es una muñeca/un juguete de látex.

Pinocchio is a puppet and Barbie is a doll/a toy of latex.

La fruta que tiene más vitaminas y que se puede beber en zumo es la naranja/el pomelo de Florida.

The fruit that has most vitamins and that can be drunk as a juice is the orange/the grapefruit of Florida.

Si buscas a Ana, está preparando la comida. Supongo que está en la cocina/el comedor preparándolo todo.

If you are looking for Ana, she is preparing the lunch. I suppose she is in the kitchen/dining room preparing everything.

Mi hermano se cayó esquiando y se rompió la pierna/el brazo el año pasado.

My brother fell off skiing and he broke his leg/arm last year. 


$$
\text { pise }
$$




$$
\text { pise }
$$




\footnotetext{
${ }^{1}$ Another early negativity was visually observed between 0 and $150 \mathrm{~ms}$ but analyses revealed no main effect of Expectation $(F(1,19)=2.53, p=.13)$ and no interaction Expectation $\times$ Region $(F(2,38), 0.69$, $p=.93)$.

${ }^{2}$ Note that participants were not instructed before the listening phase that the second phase of the experiment would be a memory task, which might have reduced their accuracy in the lexical recognition task. Indeed, previous studies have shown that the context of the encoding phase may affect subsequent recognition, and that recognition accuracy rate may be reduced when participants are not clearly instructed to memorize words (Coane \& Balota, 2010; Finnigan, Humphreys, Dennis, \& Geffen, 2002).

${ }^{3}$ Note that the sentences marked by an asterisk mistakenly contain a gender marked adjective that will be replaced for future use.
} 